\title{
Anti ulcer activity of ethanol extract of the stem bark of Careya arborea Roxb.
}

\author{
${ }^{*}$ Kamal Kumar ${ }^{1}$, Kenganora Mruthunjaya ${ }^{2}$, Satish Kumar³, Rajendran Mythreyi ${ }^{4}$ \\ ${ }^{1}$ Institute of Pharmaceutical Sciences and Research Centre, Bhagwant University, Ajmer, Rajasthan, India \\ ${ }^{2} J S S$ College of pharmacy, Mysore, Karnataka, India \\ ${ }^{3}$ Gautham College of Pharmacy, Bangalore, Karnataka, India \\ ${ }^{4}$ M.S. Ramaiah College of Pharmacy, Bangalore, Karnataka, India
}

\begin{abstract}
The aim of the study was to determine anti ulcer activity of stem bark of Careya arbore Roxb. on the Wister strain albino rats. Dried stem bark of Careya arbore Roxb. was powdered and this coarse powder was extracted with $70 \%$ ethanol by soxhlet extraction method to yield a Ethanol extract of stem bark of Careya aborea Roxb. (EECA). The extract was subjected for preliminary phytochemical analysis and was evaluated for anti ulcer activity against various models such as Ethanol induced, cold restraint stress induced and Pylorus ligation induced models. In acute toxicity study, EECA was found to be safe till $3000 \mathrm{mg} / \mathrm{kg}$. So the doses of EECA at various concentration of $300 \mathrm{and} 600 \mathrm{mg} / \mathrm{kg}$ body weight was administered orally, twice daily for 5 days for prevention of ulcer from Pylorus ligation, Ethanol and cold restraint stress - induced ulcers. Analytical parameters like Percentage of Ulcer protection was calculated based on Ulcer index and Gastric juice volume, $\mathrm{pH}$ and acidity of gastric juice. Preliminary phytochemical analysis of EECA showed the presence of carbohydrates, glycosides, phytosterols, phenolic compounds, tannins and saponins. The EECA has shown significant activity at both $300 \mathrm{mg} / \mathrm{kg}$ and $600 \mathrm{mg} / \mathrm{kg}$ dose level in a dose dependent manner. Phytoconstituents like tannins and saponins may be responsible for anti ulcer activity of EECA.
\end{abstract}

Key Words: Phytochemical analysis, ulcer index, ulcer protection, gastric juice, tannins, saponins.

\section{INTRODUCTION}

Peptic ulcer is the most common gastrointestinary disorder in clinical practice (Akhtar et al., 1992). Peptic ulcer occurs due to an imbalance between the aggressive (acid, pepsin and Helicobacter pylori) and the defensive (gastric mucus and bicarbonate secretion, prostaglandins, innate resistance of the mucosal cells) factors (Tripathi, 1999). Although a number of antiulcer drugs such as $\mathrm{H}_{2}$ receptor antagonists, proton pump inhibitors and cytoprotectants are available for ulceration all these drugs have various undesirable effects such as arrhythmias, impotence and hematopoietic changes and limitations (Ariyoshi et al., 1986; Del et al., 1985). There are many agents in alternative medicine, which have shown promising antiulcer activity without producing above mentioned adverse

\footnotetext{
*Corresponding Author:

Kamal Kumar

Research Scholar

Institute of Pharmaceutical Science and Research centre

Bhagwant University, Ajmer (Rajasthan)-305004, India

E-mail: kamalg82@gmail.com

Contact No.: +919024711425
}

reaction. The antiulcerogenic activity of many plant products is reported due to an increase in mucosal defensive factors rather than decrease in the offensive factors (Satoskar et al., 1999; Walker et al., 2003; Tipins et al., 2003).

Careya arborea Roxb. belonging to the family Lecythidaceae is distributed throughout India, Sri Lanka and Malaya peninsula (Gamble, 2005). It is known as "Padmaka" in Ayurveda (Anonymous, 1978). Careya arborea Roxb. has ethnopharmacological uses in curing tumour, cough, bronchitis, wounds, dysentery, epilepsy, ulcer and eruptive fever (Kirtikar et al., 1999). It has been reported to posses hepato protective activity, antimicrobial and antioxidant activity, antileishmanial activity (Mandal et al., 2006), anti tumour activity (Natesan et al., 2007), anti-inflammatory and analgesic activity (Kumar et al., 2005) and CNS stimulant activity (Kumar et al., 2008). As review of literature finds no report on anti ulcer activity of the stem bark of Careya arborea Roxb, present studies were carried out to prove the folk claim of its anti ulcer activity. 


\section{MATERIALS AND METHODS}

\section{Plant material identification}

The plant material was collected from vicinity of Tirunelveli, Tamil Nadu state. The plant material collected was identified at the herbarium of M.S.Ramaiah College of Pharmacy, Bangalore and authenticated by Dr. S.N. Yoganarasimhan. The specimen was given a voucher's collection number 27 in the field. A sample of the crude drug material was also preserved in the crude drug museum of the college.

\section{Ethanol extraction}

A weighed quantity $100 \mathrm{~g}$ of the air-dried powdered drug was taken and extracted with Ethanol (70\%) in a soxhlet extractor for $72 \mathrm{~h}$. The extract was concentrated in a rotary flash evaporator at a temperature not exceeding $50^{\circ} \mathrm{C}$ and was evaporated to dryness. The EECA was subjected for preliminary phytochemical analysis.

\section{Animal}

Swiss albino mice weighing 25-30gm and Wister albino rats weighing 150-250 gm of either sex were used in the study. All the pharmacological work was carried out after obtaining the approval from the Institutional Animal Ethics Committee (Ref. No.: MSRCP/M-20/2007) of M. S. Ramaiah College of pharmacy. All animal experiments strictly complied with the approval of institutional animal ethical committee. The animals were kept in polyacrylic cages and maintained under standard housing conditions of temperature $\left(24-27^{\circ} \mathrm{C}\right)$ and humidity (60-65\%) with 12:12 light:dark cycles. They were acclimatized for seven days. Food was provided in the form of dry pellets and water ad libitum.

\section{Acute toxicity studies}

Acute toxicity studies were carried out to study acute toxic effects of the drug and to determine minimum lethal dose of the drug extracts. The EECA were administered orally to separate groups of overnight fasted mice at doses of 30, 100, 300, 1000 and $3000 \mathrm{mg} / \mathrm{kg}$. After administration of the extracts, the animals were observed continuously for the first three hours, for any toxic manifestation like increased motor activity, salivation, acute convulsion, coma and death. Thereafter, observations were made at regular intervals for $24 \mathrm{~h}$.
Further, the animals were under observation up to a period of 1 week (Kulkarni et al., 2005)

\section{Ethanol induced gastric ulcer model}

Wister strain albino rats were divided into four groups; each group consists of 6 animals. All animals received treatment for 5 days. Group I: Control ( $2 \% \mathrm{v} / \mathrm{v}$ Tween $80,5 \mathrm{ml} / \mathrm{kg})$, p.o; Group II: Ranitidine $30 \mathrm{mg} / \mathrm{kg}$ body weight, p.o; Group III: EECA of $300 \mathrm{mg} / \mathrm{kg}$ body weight, p.o; and Group IV: EECA of $600 \mathrm{mg} / \mathrm{kg}$ body weight, p.o. were used. Gastric ulcers were induced in rats by administration of $1 \mathrm{ml} 90 \% \mathrm{v} / \mathrm{v}$ ethanol p.o. Animals were fasted for $24 \mathrm{~h}$ with free access to water prior to the test. EECA, control (2\% Tween 80$)$ and the standard drug (ranitidine) were given orally 30 minutes before administration of ethanol $(90 \% \mathrm{v} / \mathrm{v}, 1$ $\mathrm{ml} / 200 \mathrm{~g}$ ) and sacrificed after 15 minutes. The stomach was dissected out, gastric juice was collected and its volume was measured. The stomach was opened along the greater curvature, rinsed under a stream of water and pinned flat on a corkboard. Erosions formed on the glandular portion of stomach were counted and each was given a severity rating on 1-3 scale, based on diameter of the ulcer. The overall total diameter of ulcers in one stomach divided by factor 10 was designated as ulcer index (UI) (Gosh, 2005; Hollard et al., 1985).

\section{Cold Restrain stress induced gastric ulcer model}

Wister strain albino rats were divided into four groups, each group consists of 6 animals. All animals received treatment for 5 days. Group I: Control (2\% v/v Tween 80, $5 \mathrm{ml} / \mathrm{kg})$, p.o; Group II: Ranitidine $30 \mathrm{mg} / \mathrm{kg}$ body weight, p.o; Group III: EECA $300 \mathrm{mg} / \mathrm{kg}$ body weight, p.o; and Group IV: EECA $600 \mathrm{mg} / \mathrm{kg}$ body weight, p.o. were made. Animals were deprived of food for $12 \mathrm{~h}$ with free access to water prior to the tests. The EECA, control ( $2 \%$ Tween 80$)$ and standard drug ranitidine were administered 30 mins prior to immobilizing the animals. For stress induced ulcers, $30 \mathrm{mins}$ after administration of drugs, each animal was individually immobilized in a stress cage and kept for $3 \mathrm{~h}$ in a refrigerator, maintained at $4-6^{\circ} \mathrm{C}$. The animals were sacrificed by a blow on the head, stomach isolated and gastric juice was collected, volume, $\mathrm{pH}$ and total acidity of gastric juice were determined. The stomach was opened along the greater curvature, rinsed under a stream of water and pinned flat 
on a corkboard. Erosions formed on the glandular portion of the stomach were counted and each given a severity rating on 1-3 scale based on diameter of ulcers. The overall total diameter of ulcers in one stomach divided by factor 10 was designated as ulcer index (UI) (Khare et al., 2008).

\section{Pyloric ligation model}

The ulcer protective effect of EECA was studied as per the method of (Shay et al., 1945). In pyloric ligation induced ulcers, ulcers are caused by accumulation of acidic gastric juice in stomach. Wister strain albino rats were divided into four groups; each group consists of 6 animals. All animals received treatment for 5 days. Group I: Control ( $2 \%$ v/v Tween 80, $5 \mathrm{ml} / \mathrm{kg}$ ), p.o; Group II: Ranitidine $30 \mathrm{mg} / \mathrm{kg}$ body weight, p.o; Group III: EECA $300 \mathrm{mg} / \mathrm{kg}$ body weight, p.o; and Group IV: EECA $600 \mathrm{mg} / \mathrm{kg}$ body weight, p.o. were formed. Albino rats were fasted for $24 \mathrm{~h}$ with free access to water prior to the tests. Under light ether anesthesia, the abdomen was opened by a small midline incision below the xiphoid process; the pyloric portion of the stomach was slightly lifted out and ligated, avoiding traction to the pylorus or damage to its blood supply. The stomach was replaced carefully and the abdominal wall closed by interrupted sutures. Control vehicle, EECA and standard drug (ranitidine $30 \mathrm{mg} / \mathrm{kg}$ ) were administered orally immediately after pyloric ligation. After $4 \mathrm{~h}$ of pyloric ligation, the animals were sacrificed with excess of anesthetic ether and stomach was dissected out; the gastric contents were drained into graduated tubes and its volume, $\mathrm{pH}$, total acidity were determined. Glandular portion of stomach was cut open along the greater curvature and inner surface examined for ulceration. Stomach was rinsed under a stream of water and pinned flat on a corkboard. As in Table 1 Erosions formed on the glandular portion of stomach were counted and each given a severity rating on a 1-3 scale based on diameter of ulcers. The overall total diameter of ulcers in one stomach divided by a factor 10 was designated as ulcer index (UI).

The percentage ulcer protection was calculated using the formula -

Percentage of ulcer protection $=1-\left[\frac{\mathrm{Ut}}{\mathrm{Uc}}\right] \times 100$

where $\mathrm{Ut}=$ Ulcer index of treated group and $\mathrm{Uc}=$ Ulcer index of the control group.
Table 1: Rating scale for ulcer diameter.

\begin{tabular}{ccc}
\hline Sl. No. & Ulcer diameter & Rating scale \\
\hline 1 & $\leq 1 \mathrm{~mm}$ & 1 \\
2 & $>1 \mathrm{~mm} \leq 2 \mathrm{~mm}$ & 2 \\
3 & $>2 \mathrm{~mm}$ & 3 \\
\hline
\end{tabular}

The gastric juice was titrated against $0.01 \mathrm{~N} \mathrm{NaOH}$ using Topfer's reagent as indicator to find out the free acidity and total acidity (Ganguly et al., 1973).

\section{RESULTS}

Phytochemical analysis

On phytochemical analysis of EECA, the extract has shown the presence of Carbohydrates and glycosides, Phytosterols, Phenolic compounds and tannins, saponins.

\section{Acute toxicity studies}

Acute toxicity studies were carried out on mice for EECA at doses of 30, 100, 300, 1000 and $3000 \mathrm{mg} / \mathrm{kg}$ body weight. Each dose was administered to separate groups of mice. No toxic symptoms or death was observed in any of the animals up to the dose of $3000 \mathrm{mg} / \mathrm{kg}$ body weight with either extracts, up to one week.

\section{Ethanol induced gastric ulcer model}

Table 2 indicates the significant antiulcer activity of EECA at the both doses. Ulcer index reduced at both doses, but the dose $600 \mathrm{mg} / \mathrm{kg}$ is significant one. Percentage of ulcer protection of $600 \mathrm{mg} / \mathrm{kg}$ is more when compared to $300 \mathrm{mg} / \mathrm{kg}$ and the volume of the gastric juice in $\mathrm{ml}$ is also reduced in EECA (600 $\mathrm{mg} / \mathrm{ml}$ ). Hence, it can be said that both extracts have anti ulcer activity, but EECA at $600 \mathrm{mg} / \mathrm{kg}$ is more potent.

Table 2: Effect of EECA on ethanol induced ulcers.

\begin{tabular}{|c|c|c|c|c|}
\hline $\begin{array}{l}\text { Sl. } \\
\text { No. }\end{array}$ & Treatment & $\begin{array}{c}\text { Ulcer index } \\
(\text { mean } \pm \text { SEM) }\end{array}$ & $\begin{array}{c}\% \text { Ulcer } \\
\text { protection }\end{array}$ & $\begin{array}{c}\text { Vol. of gastric } \\
\text { juice (ml) }\end{array}$ \\
\hline 1 & Control & $5.733 \pm 0.1626$ & - & $2.966 \pm 0.0494$ \\
\hline 2 & $\begin{array}{l}\text { Ranitidine } \\
(30 \mathrm{mg} / \mathrm{kg})\end{array}$ & $0.683 \pm 0.1167^{* * *}$ & $88.09 \%$ & $1.716 \pm 0.08724^{* * *}$ \\
\hline 3 & $\begin{array}{c}\text { EECA } \\
(300 \mathrm{mg} / \mathrm{kg})\end{array}$ & $2.183 \pm 0.2257^{* * *}$ & $61.92 \%$ & $2.3 \pm 0.03651^{* * *}$ \\
\hline 4 & $\begin{array}{c}\text { EECA } \\
(600 \mathrm{mg} / \mathrm{kg})\end{array}$ & $0.866 \pm 0.1116^{* * *}$ & $84.89 \%$ & $2.01 \pm 0.07491^{* * *}$ \\
\hline
\end{tabular}

Values expressed as mean \pm SEM; One way Analysis of Variance (ANOVA) p< 0.0001; Tukey Kramer Multiple Comparison Test;

*** $\mathrm{P}<0.001$ when compared with control group. 
Table 3: Effect of EECA on Cold stress induced gastric ulcer.

\begin{tabular}{ccccccc}
\hline S1. No & Treatment & $\begin{array}{c}\text { Ulcer index } \\
(\text { mean } \pm \text { SEM) }\end{array}$ & $\begin{array}{c}\text { \% Ulcer } \\
\text { protection }\end{array}$ & $\begin{array}{c}\text { Vol. of gastric juice } \\
(\mathbf{m l})\end{array}$ & pH & $\begin{array}{c}\text { Total acidity } \\
\text { meq/1/100g }\end{array}$ \\
\hline 1 & $\begin{array}{c}\text { Control } \\
\text { Ranitidine }\end{array}$ & $3.85 \pm 0.2566$ & - & $3.633 \pm 0.0557$ & $2.133 \pm 0.076$ & $67.5 \pm 1.607$ \\
2 & $\begin{array}{c}0.7167 \pm 0.1167^{* * *} \\
(30 \mathrm{mg} / \mathrm{kg})\end{array}$ & $81.38 \%$ & $1.9 \pm 0.0730^{* * *}$ & $3.583 \pm 0.065^{* * *}$ & $43.17 \pm 1.014^{* * *}$ \\
3 & $\begin{array}{c}\mathrm{EECA} \\
(300 \mathrm{mg} / \mathrm{kg})\end{array}$ & $1.9167 \pm 0.0477^{* * *}$ & $50.21 \%$ & $2.816 \pm 0.0601^{* * *}$ & $3.033 \pm 0.049^{* * *}$ & $50.83 \pm 1.167^{* * *}$ \\
4 & $\begin{array}{c}\mathrm{EECA} \\
(600 \mathrm{mg} / \mathrm{kg})\end{array}$ & $1.1166 \pm 0.2167^{* * *}$ & $70.98 \%$ & $2.016 \pm 0.0749^{* * *}$ & $3.333 \pm 0.042^{* * *}$ & $47.17 \pm 1.167^{* * *}$ \\
\hline
\end{tabular}

Values expressed as mean \pm SEM; One way Analysis of Variance (ANOVA) $\mathrm{p}<0.0001$; Tukey Kramer Multiple Comparison Test; *** $\mathrm{P}<0.001$ when compared with control group.

Table 4: Effect of EECA on Pylorus ligation ulcer model.

\begin{tabular}{ccccccc}
\hline S1. No & Treatment & $\begin{array}{c}\text { Ulcer index } \\
(\text { mean } \pm \text { SEM) }\end{array}$ & $\begin{array}{c}\text { \% Ulcer } \\
\text { protection }\end{array}$ & $\begin{array}{c}\text { Vol. of gastric juice } \\
(\mathbf{m l})\end{array}$ & pH & $\begin{array}{c}\text { Total acidity } \\
\text { meq } / \mathbf{l} / \mathbf{1 0 0 g}\end{array}$ \\
\hline 1 & $\begin{array}{c}\text { Control } \\
\text { Ranitidine }\end{array}$ & $3.917 \pm 0.4490$ & - & $6.1167 \pm 0.1014$ & $2.116 \pm 0.070$ & $78 \pm 1.000$ \\
2 & $\begin{array}{c}(30 \mathrm{mg} / \mathrm{kg}) \\
\mathrm{EECA}\end{array}$ & $0.683 \pm 0.1276^{* * *}$ & $82.56 \%$ & $4.033 \pm 0.05578^{* * *}$ & $3.733 \pm 0.049^{* * *}$ & $36.67 \pm 0.333^{* * *}$ \\
3 & $\begin{array}{c}2.217 \pm 0.1621^{* * *} \\
(300 \mathrm{mg} / \mathrm{kg})\end{array}$ & $43.41 \%$ & $4.95 \pm 0.07638^{* * *}$ & $3.216 \pm 0.047^{* * *}$ & $61.33 \pm 1.229^{* * *}$ \\
& $\begin{array}{c}\mathrm{EECA} \\
(600 \mathrm{mg} / \mathrm{kg})\end{array}$ & $0.85 \pm 0.1544^{* * *}$ & $78.29 \%$ & $4.683 \pm 0.06009^{* * *}$ & $3.483 \pm 0.094^{* * *}$ & $48.83 \pm 0.872^{* * *}$ \\
\hline
\end{tabular}

Values expressed as mean \pm SEM; One way Analysis of Variance (ANOVA) $\mathrm{p}<0.0001$; Tukey Kramer Multiple Comparison Test; *** $\mathrm{P}<0.001$ when compared with control group.

\section{Cold restraint stress model}

Table 3 shows the dose dependent ulcer reduction and increase in the ulcer protection at higher dose. The volume of gastric juice also reduced at higher dose. The $\mathrm{pH}$ also shows significant reduction and acidity of the juice was also reducing significantly at higher dose. Hence EECA shows significant activity at $600 \mathrm{mg} / \mathrm{kg}$.

\section{Pyloric ligation model}

Table 4 shows the significant reduction of ulcer index at EECA $600 \mathrm{mg} / \mathrm{kg}$, and increased ulcer protection percentage of EECA is high at $600 \mathrm{mg} / \mathrm{kg}$. And the volume of gastric juice was also reduced at higher dose and acidity was also reduced at higher dose.

\section{DISCUSSION}

Antiulcer activities were performed on Wister rats of either sex using ethanol induced, cold stress induced and pyloric ligation models. The 70\% Ethanol extracts (300 and $600 \mathrm{mg} / \mathrm{kg}$ ) showed significant antiulcer activity. The anti ulcer activity was carried out in three different Models, the Model such as Pylorus ligation (PL), Ethanol (EtOH) and cold restraint stress (CRS) - induced ulcers. The percentage ulcer protection is been observed in all the Models, but the extent of percentage protection is more in ethanol induced ulcer and pyloric ligation ulcer. The percentage of ulcer protection variance with the standard ranitidine $30 \mathrm{mg} / \mathrm{kg}$ and EECA $600 \mathrm{mg} / \mathrm{kg}$ is very less when compared to cold stress induced ulcer. The ulcer index is also reduced in the higher dose. The volume of gastric juice is reduced in all the Models and $\mathrm{pH}$ value is also reduced significantly in cold stress induced and pyloric ligation Models. The acidity of the urine collected in the cold stress induced and pyloric ligation Models are also reduced significantly. The phytoconstituents like flavonoids, tannins, terpenoids, and Saponin have been reported in several anti-ulcer literatures as possible gastro protective agents. Flavonoids, tannins and triterpenes are among the cytoprotective active materials for which anti ulcerogenic efficacy has been extensively confirmed (Borelli et al., 2000)

Tannins may prevent ulcer development due to their protein precipitating and vasoconstriction effects. Their astringent action can help precipitating 
micro proteins on the ulcer site, thereby forming an impervious layer over the lining that hinders gut secretions and protects the underlying mucosa from toxins and other irritants (Berenguer et al., 2005; Nwafor et al., 1996). The phytoconstituents found in the EECA were carbohydrates and glycosides, phytosterols, phenolic compounds and tannins, saponins. These phytoconstituents present in the EECA could be the possible agents in the prevention of ulcers in the rats.

\section{CONCLUSION}

The present study showed that ethanol extract of stem bark of Careya arborea Roxb. have shown significant effect on the ulcer induced by three Models such as ethanol induced, cold stress induced and pyloric ligation Model. The maximum ulcer protection of EECA has been shown in the Ethanol induced and cold stress induced models and significant effect was found at both $300 \mathrm{mg} / \mathrm{kg}$ and $600 \mathrm{mg} / \mathrm{kg}$ dose levels.

\section{REFERENCES}

Akhtar, M.S., Khtar, A.H., Khan, M.A. (1992) International Journal of Pharmacognosy, Volume 30, Pages 97-98. [DOI]

Anonymous. (1978) Ayurvedic Formulary of India. Part-I; $1^{\text {st }}$ ed. New Delhi: Government of India, Pages 6.

Ariyoshi, I., Toshiharu, A., Sugimura, F., Abe, M., Matsuo, Y., Honda T. (1986) Recurrence during maintenance therapy with Histamine $\mathrm{H} 2$ antagonist in cases of gastric ulcer. Nihon University Journal of Medicine. Volume 28, Pages 69-74.

Berenguer, B., Sanchez, L.M., Qulilez, A., Lopez barreiro, Galvez, J., Martin, M.J. (2005) Protective and antioxidant effects of Rhizophora mangle L. against NSAID-induced gastric lesions. J Ethnopharmacol, Volume 103, Pages 104-200.

Borelli, F., Izzo, A.A.(2000) The plant kingdom as a source of antiulcer remedies. Phytotherapy Research, Volume 14, pages 581-91. [DOI]

Del Soldato P., Foschi D., Varin L., Daniotti S. (1985) Comparison of the gastric cytoprotective properties of atropine, ranitidine and PGE2 in rats. European Journal of Pharmacology. Volume 106: Pages 53-58. [DOI]

Gamble, J.S. (2005) The flora of the presidency of Madras. Vol 1.Dehradun: BSI (reprinted), Pages 102-113.

Ganguly, A.K., Bhatnagar, O.P.(1973) Effect of bilateral adrenalatomy on production of restrain ulcer in the stomach of albino rat. Canadian Journal of Physiology and Pharmacology. Volume 51,Pages 748-750. [DOI]

Ghosh, M.N. (2005) Fundamentals of Experimental Pharmacology. $3^{\text {rd }}$ ed. Kolkata: Hilton and Company, Pages 153-158.
Hollander, D., Taranawski, A., Krause, W.J., Gergely, H.(1985) Protective effect of sucralfate against alcohol-induces gastric mucosal injury in the rat. Gastroenterology, Volume 88, Pages 366-374.

Khare, S., Asad, M., Dhamanigi, S.S., Satya Prasad, V. (2008). Antiulcer activity of cod liver oil in rats. Indian Journal of Pharmacology, Volume 40, issue 5, Pages 209-214. PMid:20040959 PMCid:2792623

Kirtikar, K.R., Basu, B.D. (1991) Indian Medicinal plants. $2^{\text {nd }}$ edn, Allahabad: Bishan singh mahendra Pal singh, Pages 1056-63.

Kulkarni, S. K. (2005) Handbook of Experimental Pharmacology. $3^{\text {rd }}$ ed. Vallabh Prakashan, Delhi, Pages 148-150. PMid:23120157 PMCid:3450965

Kumar, R.S., Sivakumar, T., Sundram, R.S., Sivakumar, P., Nethaji, R., Senthil, V.(2005) Anti-inflammatory and analgesic effects of Careya arborea stem bark in experimental models. Nigerian Journal of Natural Product and Medicine. Volume 9, Pages 38-43.

Kumar, R.S., Sundram, R.S., Sivakumar, P., Nethaji, R., Senthil, V., Murthy, N.V.(2008) CNS activity of the methanol extracts of Careya arborea in experimental animal model. Bangladesh Journal of pharmacology, Volume 3, Pages 36-43.

Mandal, D., Panda, N., Kumar, S., Banerjee, S., Mandal, NB., Sahu, N.P.(2006) A triterpenoid saponin possessing antileishmanial activity from the leaves of Careya arborea. Phytochemistry Volume 67, issue 2, Pages 183-190. [DOI]

Natesan, S., Badami, S., Dongre, S.H., Godavarthi, A.(2007) Antitumor activity and antioxidant status of the methanol extract of Careya arborea bark against dalton's lymphoma ascites-induced ascetic and solid tumor in mice. Journal of Pharmacological Sciences. Volume 103, Pages 12-23. [DOI]

Nwafor, P.A., Effrain, K.D., Jack, T.W. (1996) Gastroprotective effects of aqueous extract of Khaya senegalensis bark on indomethacin-induced ulceration in rats. West African Journal of PharmacologyandDrugresearch, volume12, Pages 46-50.

Satoskar, R.S., Bhandarkar, S.D., Ainapure, S.S. (1999) Pharmacology and Pharmacotherapeutics, $16^{\text {th }}$ edn, Popular prakashan, Mumbai.

Sharma, P.C., Yelne, M.B., Dennis, T.J. (2001) Database on Medicinal Plants used in Ayurveda. New delhi: Dept. of ISM \& H, Min of Health \& family Welfare, Volume 6, Pages 103109.

Shay, H., Komarov, S.A., Fels, S.S., Meranze, D., Gruenstein, M., Siplet, H.(1945) A simple method for uniform production of gastric ulceration in the rat. Gastroenterology, Volume 5, Pages 43-61.

Tipnis, H.P., Bajaj, A. (2003) Clinical pharmacy. 1st ed., Career Publication, Nashik, Pages 80-1.

Tripathi, K.D. (1999). Essentials of Medical Pharmacology. Jaypee Brothers Medical Publishers (P) Ltd. New Delhi, Pages 628642 .

Walker, R., Edwards, C. (2003) Clinical pharmacy and therapeutics. $3^{\text {rd }}$ edn. Edinburgh: Churchill Livingstone International edition, Pages 55. 